\title{
EFFECTIVE TEACHING TECHNIQUES AT THE TERTIARY LEVEL
}

\section{Zofia Krawczyk-Bernotas}

Faculty Manager, Australian Institute of Music,

1-55 Foveaux Street, Surry Hills, NSW 2010, Australia

zofia@aim.edu.au

Anthony G Shannon

Associate Dean (Teaching \& Learning), Australian Institute of Music, \&

Registrar, Campion College, PO Box 3052, Toongabbie East, NSW 2146, Australia

tshannon@aim.edu.au, t.shannon@campion.edu.au

\section{ABSTRACT:}

It is always useful and timely for teachers to go back to basic principles and to revise their teaching plans. It is important to remind yourself what you are doing, and why you are doing it. What do you hope to achieve? With these ideas in mind, teachers can then set specific goals for their teaching plans. This article will look at some basic teaching methods that can be applied to help achieve specific educational goals at the tertiary level. The implementation of ideas for improvement can often be lost if the teaching climate in which they are tried is not simple, structured and appropriate.

Keywords: Formal schooling, tertiary education, motivation, control, learning styles, feedback, lectures, seminars, tutorials.

Academic Discipline And Sub-Disciplines: Education, Didactics of the classroom TYPE (METHOD/APPROACH): Classroom management at the tertiary educational level

\section{Council for Innovative Research}

Peer Review Research Publishing System

Journal: International Journal of Research in Education methodology

Vol. 7, No.1

ijremeditor@gmail.com

www.ijrem.com 


\section{INTRODUCTION}

Many university lecturers have not been trained to teach, yet are expected to do so anyway. Those who have had teacher training often find that due to circumstances outside their control, such as time constraints, or class numbers, they are not practically able to put into practice the ideas that they have learned in their training, This article will aim to provide some practical best-practice techniques that teachers can utilise in the classroom even when circumstances are not ideal, so that both the teacher and the students can get the most out of lessons.

Academic staff are usually experts in their fields of study. They have a passion for their subject, as well as a vast knowledge of it, but the skills to pass this knowledge on to others is not necessarily a requirement of their employment. Many staff are expected to impart knowledge of their subject on to students without having been given the skills to do this. For this reason, many academics see teaching as something that they "have to do", which then comes across in their teaching. This can result in ineffective lessons, which are then reflected in lack of student motivation and less than ideal student achievement.

As well as this, it is easy for even the most experienced teacher to forget the essentials of structuring each class with a beginning, a middle, and an end, especially in these days of research-intensive institutional 'league tables' for universities. The taxpayer expects academic staff to teach, but they are primarily rewarded for research. Anecdotal evidence from counsellors and open responses from student questionnaires suggests that many basic principles of pedagogy are more honoured in the breach than in practice.

Regardless of what subject or level an educator is teaching, there is a set of techniques and procedures that can be utilised in order for both the teacher and the student to get the most out of the course. It is important for teachers to regularly revisit and review their teaching plans and techniques in order to keep their lessons fresh, relevant and inspiring. Teachers have a large number of techniques and tools at their disposal, which they need balance in the most appropriate way for their particular subject and their particular group of students. The teaching approaches and methods, which will be described below transcend both subject matter and subject level and can be applied to all courses.

\section{FORMAL SCHOOLING THROUGHOUT HISTORY}

Humans are born to learn. Civilisation as we know it depends on this ability and its progress, at least in the Western sense, is based on humans learning skills and ideas. In fact, many cultures and religions believe that we are born into this world to learn certain lessons and when we have learnt these, we can achieve higher levels of being. Education therefore, is an essential aspect of any functioning society [1].

Formal schooling in the Western tradition began in Ancient Greece, where groups of thinkers gathered together to discuss philosophical and universal ideas. These discussions began as informal, relaxed gatherings (the Ancient Greek word scholé, which is the origin of the English "school", means "leisure", or "recreation"), but soon became formalised, and it wasn't long before schools started to enforce the rigid rules that form the basis of modern schooling. For example, Ancient Greek students would all sit on a bench with a writing stylus in their hand and a tablet on their lap. In Ancient Rome, teaching consisted of question and answer recitals.

Desks and notebooks were introduced to schools in the fifteenth century. In the sixteenth century, printing was invented, which led to uniform textbooks being given to all students. This in turn led to stricter grading systems, which continued to improve throughout the eighteenth, nineteenth and twentieth centuries, although all improvements and changes were contained within the original framework. Formal education for girls (in the traditional sense of teaching them to read and write), only started to be discussed seriously from about the seventeenth century onwards [2].

Today teaching methodologies differ around the world [3]. As the structure and ideals of a given society change, so do the expectations of what should be taught in schools and universities. This has led arguments, particularly in Western societies, about certain topics. For example, the content of what should be taught in classrooms has been a constant point of contention with some people claiming that formal institutions should stick to only teaching skills such as reading, writing, and mathematics, etc, while others believe that these also have the responsibility to teach skills and ideas that traditionally made up community learning, such as sex education and ethics.

Another point of disagreement has traditionally been the argument about who should have access to formal education. For example, in Ancient Greece, Plato believed that only those select few, who possessed natural leadership skills should receive formal schooling. In some societies, schooling was, until relatively recently, restricted to boys and men only, while in economically disadvantaged areas, it is often only those who can pay for it, who have access to schooling. In countries such as Australia, we are lucky enough to be able to offer formal education to all children and adults, regardless of gender, race, socio-economic status, or disability, although there continue to be major difficulties in provision of opportunities for some sectors of indigenous communities [4].

Because modern education is generally accessible to all in Western societies, today's teachers need to have the skills and ability to cater their teaching to a wide variety of learners and learning situations [8]

]]. They need to be able to structure their teaching so that they can impart their knowledge, and encourage motivation, to a wide range of students with various learning styles and preferences. 


\section{STUDENT MOTIVATION}

Today's teachers, particularly a the tertiary level need to be more than simply instructors. It is not enough for them to just pass on the knowledge and information that they themselves have learnt [1]. Modern teachers need to be aware that different students approach learning in different ways, and hence need to have the ability to cater to these differences. Even in a teaching-intensive institution, or a teaching-only school, there needs to be a research-based curriculum mediated by scholarship-informed teaching.

Learning requires effort and motivation on the part of the student [6]. The term "motivation" refers to the energies that direct a person's behaviour and cause them to initiate the pursuit of a goal and persist in that pursuit $[8,9]$. There is evidence that unmotivated students are not ready for this effort and are therefore not able to be effective learners at any level. One hopes that as students progress through the educational system their motivation becomes more intrinsic, though all of us respond to extrinsic motivation, particularly in the presence of a passionate teacher with the ability to inspire.

At the tertiary level, once students have achieved and completed their first year of study, there is anecdotal evidence to suggest that a large proportion of them know what their goals are and may already be sufficiently inwardly motivated to put in the required effort to learn. In contrast to this, first year tertiary students, and those who have not yet achieved this inner motivation, need to be convinced, primarily by their teachers, to push themselves to study, that is, they require outward motivation. Teachers therefore, need to possess the skills and the ability to assess the learners' needs, and to then structure their teaching to meet these needs, in order to motivate, as well as to instruct, their students [5]. Tertiary level students should be expected to take an active part in their own learning, but they cannot be left to fend for themselves. An effective teacher will tailor their lesson plans to find the right balance between passing on their knowledge and inspiring their students to keep seeking further knowledge.

What is the best way to ensure that as many students as possible learn as much as possible? By "learn", we are referring to the ability to memorise facts, as well as the ability to think critically, make decisions based on the facts and information that students have memorised, and to also develop life-long learning abilities.

There is no simple answer to this question. Therefore today's tertiary education institutions use a variety of methods to ensure that they "reach" as many students as possible. The most common methods used in Europe and the British system are: lectures, tutorials, and laboratories or other practical lessons. (American institutions also utilise these same methods but the distinction between what is meant by "lectures" and "tutorials" is often blurred.) As well as lectures, tutorials, and practical lessons, there are other methods used to impart knowledge and skills, for example, apprenticeships and practical placements, but as this article is mainly concerned with structured group learning, these methods, which most closely resemble the wider informal community learning, will not be discussed here.

\section{LECTURES AND TUTORIALS}

A lecture is typically an oral presentation, where the lecturer's intention is to present information about a particular subject to a large number of students [6]. It is a one-way method of communicating knowledge and ideas, and it does not involve any active participation on the part of the students. Modern lectures are now often accompanied by visual presentations, which enable students to use both the visual and aural channels to learn.

A lecturer needs to be an engaging and interesting speaker if they are to motivate students to make the effort to learn. This also means that a lecture requires a high level of preparation by the lecturer, as they will effectively be the sole focus of the entire length of the class. Many lecturers today also prepare handouts or other take-away resources to help students refer back to the material that has been covered in the lecture.

A tutorial is generally more interactive than a lecture. In Australia, New Zealand and Canada, a tutorial consists of about 10 - 30 students, which means that there is a possibility for the teacher to give students some individualised attention. Tutorials give students the opportunity to discuss the material that was talked about during the lecture. Some tutorials are more practical and allow students to work with the teacher and other students to solve problems and actively utilise the knowledge they have gained in the lecture.

A tutorial does not generally require as much teacher preparation as a lecture, because some of the time will be taken up by student input. However, student preparation to a tutorial, for example, preparing what questions a student would like to ask, enhances tutorial effectiveness. Without sufficient student preparation tutorials can readily degenerate into minilectures. Therefore the teacher needs to teach the students how to prepare for tutorials.

To complement lectures and tutorials, many institutions also use laboratory sessions or other types of practical lessons to further students' learning. These sessions typically allow students to utilise the knowledge and skills that they have acquired in the lectures and tutorials. Practical lessons allow kinaesthetic learners to learn by doing. As practical lessons involve a lot of student input, inward student motivation is likely to be higher, hence teacher effort and preparation does not need to be as intense as it would be in a lecture or even a tutorial.

\section{REVIEWS}

In order to determine how effective the teaching is for a given subject, it is important for teachers to conduct regular and timely reviews. For example, many tertiary institutions conduct student feedback surveys at the end of a teaching period, which give students an opportunity to provide their teachers with their perspective on how a course went. As well as 
student feedback, implementing a system of peer review of teaching, for example, one teacher sitting in on another's classes and then giving feedback, as part of the moderation and benchmarking process, can be a good way to measure the overall effectiveness of the way that the course was taught.

As there is a limited amount of goodwill available for responding to questionnaires, students need to see that their comments are seriously considered. Yet it is not uncommon for one to encounter the same unaddressed criticisms of teachers by their students after successive teaching periods.

\section{CONCLUDING COMMENTS}

No matter how talented the instructor, learning is essentially up to the learner. When it comes to teaching and learning, there are so many variables to take into account that it is difficult to measure its effectiveness [3]. All students and teachers are individuals, therefore there is no single method of instruction that will cater to all students and utilise a particular teacher's skills. Because of this, modern tertiary institutions use a variety of methods to maximise student learning.

The most effective way to teach students therefore, is to utilise a variety of instruction methods, which cater to individual students' learning styles, ensuring that all motivating tactics are being used. Using various instructors to provide teaching in a single subject adds variety and can increase interest and student motivation, but it is important to maintain consistency. In practice, anecdotal evidence suggests that in order to maintain consistency, the number of teachers teaching one course should not surpass three. An effective class is one that is focused on what is learned at the end of it, rather than the way it was taught.

It is easy for teachers to forget the basic skills they acquired in their teacher education programs (where these even exist for post-secondary teachers) if they do not actively and deliberately put their techniques into practice. This is also a timely reminder that big issues will fail if teachers forget the basics of teaching. The approaches described above can be tailored to help teachers be the most effective that they can be. Even the best ideas can be lost if the teaching is poor.

\section{REFERENCES}

1) Bowen, J. \& Hobson, P.R. 1987. Theories of Education: Studies of Significant Innovation in Western Educational Thought. John Wiley \& Sons, Brisbane.

2) Boyd, W \& King, E.J. 1977. The History of Western Education. Adam \& Charles Black, London.

3) Highet, Gilbert. 1970. The Art of Teaching. Methuen \& Co Ltd., London.

4) Kasper, Walter. 2015. Looking Backwards for Constitutional Change. Quadrant. 59 (1-2): 41-50.

5) Killen, R. 2009. Effective Teaching Strategies: Lessons from research and practice. ( $5^{\text {th }}$ ed.) Cengage Learning Australia, Melbourne.

6) Miller, M.D., Linn, R.L. \& Gronlund, N.E. 2009. Measurement and Assessment in Teaching. Pearson Education Ltd., New Jersey.

7) Mills, H.R. 1990. Teaching and Training: A Handbook for Instructors. MacMillan Education Ltd. Hong Kong.

8) Samuels. Brian. 2015. Practical Control in the Classroom. Education Today. 65 (1): 12-16.

9) Woolfolk, A.E. \& McCune-Nicolich, L. 1984. Educational Psychology for Teachers (2 ${ }^{\text {nd }}$ Ed.). Prentice-Hall Inc., Englewood Cliffs, New Jersey. 


\section{AUTHORS' BIOGRAPHIES WITH PHOTOS}

\begin{tabular}{l|l|} 
Zofia has worked for several large tertiary education providers in Australia and \\
New Zealand, in both teaching and administrative roles. She has also worked \\
as a tutor and instructor in various fields and has taught English, English as a \\
Second Language, Polish, mathematics, and swimming. She has a Master of \\
Education Leadership degree from the University of New South Wales, an \\
Honours Bachelor of Science degree majoring in Psychology from Victoria \\
University of Wellington in New Zealand, and is also a qualified counselor. \\
She has been working at the Australian Institute of Music for the past six \\
years, where amongst other things, she has developed training resources for \\
teaching staff to help them prepare and plan lessons and assessments for \\
undergraduate and postgraduate students.
\end{tabular}

\begin{tabular}{|l|l|}
\hline & $\begin{array}{l}\text { Professor A. G. (Tony) Shannon AM is an Adjunct Professor of Central } \\
\text { Queensland University and an Emeritus Professor of the University of } \\
\text { Technology, Sydney, where he was Foundation Dean of the UTS Graduate } \\
\text { Research School and Professor of Applied Mathematics, and where he is } \\
\text { currently doing research in the Centre for Health Technologies within the } \\
\text { Faculty of Engineering and Information Technology. He holds the doctoral } \\
\text { degrees of Ph.D., Ed.D. and D.Sc. He is co-author of numerous books and } \\
\text { articles in medicine, mathematics and education. His research interests are in } \\
\text { the philosophy of education, number theory, and epidemiology, particularly } \\
\text { through the application of generalized nets and intuitionistic fuzzy logic. He } \\
\text { has taught and mentored at all levels from primary school to post-doctoral. } \\
\text { Professor Shannon is a Fellow of several professional societies. He is } \\
\text { presently Registrar of Campion College, a liberal arts degree granting } \\
\text { institution in Sydney. In June 1987 he was appointed a Member of the Order } \\
\text { of Australia (AM) for services to education. }\end{array}$ \\
\hline
\end{tabular}

